\title{
Dynamics of Upper Caste Paramountcy as Expressed in Dalit Literature: A Reading of Sharankumar Limbale's Akkarmashi
}

By Muhamed Shehin TV

Abstract- Dalit literature is a kind of writing that evolved after independence. The beginning of Dalit literature has significant historical relevance. Similar writings exploring the lives and the pathetic existence of the marginalized and downtrodden sections feature in many other countries also, cutting across borders.

Arjun Dangle has defined Dalit literature as one which familiarises the readers with the age-old caste system and untouchability in India. As we know, the caste system in India has always relegated Dalits to the marginalized 'other' side of Indian society; in other words, they were fully excluded from the social mainstream. So when they began protesting after centuries of silence, a new kind of literature came to the fore that depicted an assertion of human rights, self-esteem, revolt against social oppression, stories of personal and collective suffering, and put forth a vision of a new society sans any discrimination. The word Dalit is not new; it was in use in the 1930s as the Hindi and Marathi translation of 'Depressed classes,' a term the British used for the present-day Scheduled Castes.

Keywords: dalit literature, untouchability, depressed classes, scheduled castes, resistance literature.

GJHSS-G Classification: FOR Code: 130399

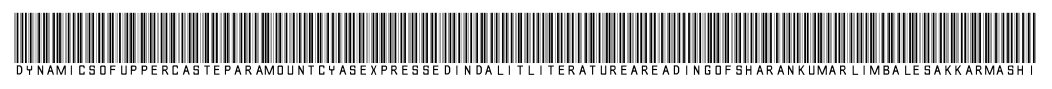

Strictly as per the compliance and regulations of:

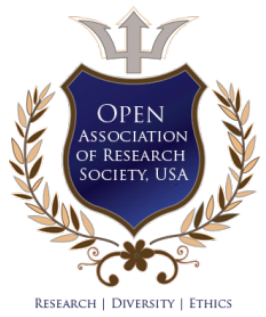

(C) 2020. Muhamed Shehin TV. This is a research/review paper, distributed under the terms of the Creative Commons AttributionNoncommercial 3.0 Unported License http://creativecommons.org/licenses/by-nc/3.0/), permitting all non-commercial use, distribution, and reproduction in any medium, provided the original work is properly cited. 


\title{
Dynamics of Upper Caste Paramountcy as Expressed in Dalit Literature: A Reading of Sharankumar Limbale's Akkarmashi
}

\author{
Muhamed Shehin TV
}

Abstract-Dalit literature is a kind of writing that evolved after independence. The beginning of Dalit literature has significant historical relevance. Similar writings exploring the lives and the pathetic existence of the marginalized and downtrodden sections feature in many other countries also, cutting across borders.

Arjun Dangle has defined Dalit literature as one which familiarises the readers with the age-old caste system and untouchability in India. As we know, the caste system in India has always relegated Dalits to the marginalized 'other' side of Indian society; in other words, they were fully excluded from the social mainstream. So when they began protesting after centuries of silence, a new kind of literature came to the fore that depicted an assertion of human rights, self-esteem, revolt against social oppression, stories of personal and collective suffering, and put forth a vision of a new society sans any discrimination. The word Dalit is not new; it was in use in the 1930s as the Hindi and Marathi translation of 'Depressed classes,' a term the British used for the present-day Scheduled Castes.

The main aim of Dalit literature is the emancipation of the Dalit community. Sharan Kumar Limbale has said: "Dalit literature is exactly that literature which aesthetically captures the trauma, sorrow, embarrassment, humiliation, ridicule, and sufferings confronted by the Dalits." Some of the accomplished Dalit writers whose writings will find a place in the resistance literature the world over are: Mahasweta Devi, Namdeo Dhasal, Daya Pawar, Arjun Dangle, Perumal Murugan, D.Gopi, Neerave Patel, Poomani, Basudev Sunni, Sachi Rautray, and Mangal Rathod.

Keywords: dalit literature, untouchability, depressed classes, scheduled castes, resistance literature.

\section{Dalit literature: Definition, Scope, POLITICS}

( alit literature is conspicuous for its condemnation of the caste system and all sorts of discrimination and by its emphasis on the elimination of social hierarchies. It is the literature of a commitment towards an egalitarian society. It questions the marginalization and exclusion of the Dalit community from the social mainstream. It is a mode of literature that upholds equality, self-esteem, and human dignity. The Dalit writers are of the view that the central purpose of creating pieces of writing is to bring about a change in the social milieu rather than amusement or display of

Author: Assistant Professor, Department of English, College of Applied Sciences, Thamarassery, Kerala. e-mail: shehinmuhamed@gmail.com literary scholarship. According to Baburao Bagul: "Dalit literature is not a literature of revenge and hatred. It primarily upholds man's dignity and freedom and, because of this very reason, it is a historic necessity. Frustration, anguish, and disappointment alone do not characterize Dalit Literature. We need literature full of life and energy for the building of a new society". All Dalit literature can be said to be more realistic rather than romantic and stands unified in their mode of the depiction of oppression and exploitation. Dalit writers are severely condemning of the reticence of the mainstream literature about the harsh social realities and their romanticization of the Indian society. Even though upper caste writers have produced literature voicing concern for the Dalits, they are usually viewed as condescending and targeted at making the Dalit resistance less powerful. As such, the writers like Mulkraj Anand or Arundhati Roy, who authored several works illustrating the trauma of the Dalits, are not representative of genuine Dalit sensibilities and mindscape. Dalit writers have employed such language, slang, and vernacular expressions, which are, by usual standards of evaluation, unacceptable and vernacular by the connoisseurs of mainstream literature. Dalit writers have also started to evolve theories of literary criticism from Dalit viewpoints. Dalit writing has an inclination towards the Marxist and Ambedkarite ideologies about its thematic content.

Even though Dalit literature as a new mode of expression could make an identity for itself only in the $19^{\text {th }}$ century, it doesn't mean Dalit characters were absent in Indian literature; of course, they also found a vast depiction in our writings. Gitanjali, authored by Rabindranath Tagore deals with how the untouchable communities are humiliated in our society. Yet another work Sadgati (1931) by Premchand focused on the oppression, exploitation, and slavery confronted by the Dalits through its protagonist Dukhi, a lower caste man. There are numerous other instances of well-known writings depicting the Dalit population and their mindscape; however, the problem was that most of these writers belonged to upper caste communities. In other words, even before the arrival of Dalit literature as a distinct genre in India, the Dalit characters were represented in literary texts, but by upper-caste writers. Here is precisely where the debate of sympathy and 
empathy gains relevance. A majority of the Dalit activists believe that only a person born as Dalit can realistically portray the plight of the community; according to Ramnika Gupta, "only ash is aware of the sensation of burning."

It is worthwhile to say that Dalit literature in India has grown both in quality and quantity, capable enough to pose a significant challenge to the so-called mainstream literature. It has successfully tackled the Brahmanical hegemony in our social landscape and literature and enabled the Dalits to assert their rights and give vent to their long-suppressed anguish; in fact, it has given the Dalits an identity of their own.

\section{il. Narrativising Hegemony}

Akkarmashi is Sharankumar Limbale's autobiography, which sheds light on the story of his childhood and growth as a half-caste, and in its power to evoke empathy, it is often talked about in the same breath as Sterne's Tristram-shandy, and Jean Genet's A Thief's journal. The miseries of being a single-parent child, the life of severe poverty, caste-based discrimination, and separation find expression in work.

Akkarmashi, written when Limbale was 25 years old, portrays the meta-realistic vignettes of his life as a Dalit in particular and which is applicable to any individual born into the Mahar community in general. While conceptualizing 'self' through his narrative, he delves into the grassroots of the Indian caste hierarchy, repudiating its very foundations that thrive on religious dogmas. In the text, the writer oscillates between the individual 'l' and the collective 'we.' The experiences of oppression and boycott of both the self and the community are the critical sources used to create 'testimonies of caste-based exploitation, anti-caste uprising, and resistance movements'.

The introductory chapter of Limbale's Akkarmashi describes his life during his primary school days when he takes cognizance of the grim reality that he was an untouchable since he belonged to the Mahar community. Here, he unconsciously comes to accept the disparity between the higher caste students and him because of imposed segregation and differences in eating habits, dressing, and even in the games. Limbale writes:

"The Wani and Brahmin students amused themselves playing Kabbadi. Being branded as untouchables, we were not supposed to play alongwith them. So Mallya, Umbrya, Parshya, all belonging to my caste, started playing touch and go. We played one sort of game, whereas the upper caste boys indulged in another. The two games were played separately like two separate whirlwinds."

Dalits have been boycotted and branded as impure. A Dalit is tagged 'untouchable' on account of his birth in the low caste, and all kinds of harassments become the legacy that he inherits from his predecessors. Limbal narrates instances where people from his community are not allowed entry into temples; also, they were not supposed to touch the public well or take water from it in spite of the fact that they themselves dug the well. Limbal writes: "The spade and the ax of our community was made use of while digging the well. We sweated it out day and night for it. It is because of the Mahars that there is adequate water inside the well. But presently, the same Mahars are not supposed to take water from the well, not even to quench their thirst". There are some customs and tradition which the Dalits have to compulsorily follow and against which they can't express their resentment within the framework of a caste-based society. In his autobiography, Limbale depicts the treatment meted out to a Dalit Rambaap by an upper-caste man named Shivram in a scene of the latter's tea shop. He writes:

Rambaab used to drink tea from Shivram's shop. After having tea, he had to wash the glass and put it back to the shelf.. He had to place the money for the tea on the table or drop it into the hands of the owner from a height because as far as a Mahar was concerned, handing money directly to anyone was considered a sin. Rambaap would notice me watching him do all this, and he would say that we belonged to the lower castes, and what I had seen was a long tradition that we had inherited from our predecessors. He would rue the fact that it was not possible to do anything about it since we were not supposed to go against the village customs.

The most remarkable aspect in Limbale's autobiography is his attitude towards women. There are many women characters who go through some serious complications in their lives; in the narrative, we come across widows, childless women, abandoned women, and concubines. While Dalit men become victims based on caste and class, Dalit women face double oppression- by the upper caste men as well as by the men of their community. Limbal introduces his mother, who has been cheated and exploited in every relationship she is involved in and burdened with the responsibility of looking after children and their upbringing. Their struggle is, on one level, for survival and on another to safeguard themselves from the unfavorable social milieu. According to Limbale, the primary handicap of a Dalit woman is her lack of education. The author, however, exhibits a good understanding of their miseries; there is no cursing or castigating them in this work. There is not even a tone of sympathy for them in the narrative, which is because of the peculiar conception of the author regarding their portrayal; he wants to depict them as strong and powerful human beings who fight against all adversities rather than as those who surrender meekly to gender and caste-based discrimination. It is this depth of 
character sketch that makes Limbale's Akkarmashi unique in the genre of Dalit life narratives. Limbal denounces the hypocrisy of the upper caste men who distort caste rules to indulge in sexual pleasures by exploiting the dignity and self-esteem of the Dalit women. His critique of the Indian caste-system is noteworthy:

Those who enjoy high caste privileges, the authority granted by religion, and inherit property, have subjugated the Dalits of this country. The Patils in every village have forcibly made the wives of Dalit farm laborers their concubines. A poor Dalit girl on attaining sixteen years of age has fallen prey to their lust. There are Dalit families who sustain themselves by offering sexual favors to the Patils.

It was quite a bizarre custom in Maharashtra that Dalit girls, as soon as they attained puberty, were kept by landlords as concubines for their sexual gratification. It was a custom for all Dalit families to "offer their daughters to the high caste Patils". In return for their sexual favors, these women got shelter and a few other provisions to live. The children born to them remained half caste or Akkarmashi, as Limbale addresses them in the novel. The whole work focuses on the identity crisis confronted by a half-caste man who is an illegitimate child born to a Mahar mother and Maratha father.

The underlying theme of Akkarmashi is the identity crisis faced by the author. As mentioned by Limbale in his Author's Note, he doesn't claim to have a good pedigree. All that he knows about his family line is that it ends with his mother and grandmother. His mother was an untouchable Mahar, and his father belonged to a privileged caste in Maharashtra. His mother lived in a cottage whereas his father lived in a big mansion. His father was a landlord, but his mother was landless. Hence, Limbale was an Akkarmashi or a half-caste. He was condemned, taunted, ridiculed and branded as illegitimate. It was through Dalit uprisings and Dalit literature that Limbale discerned that his mother was not an adultress but the victim of an oppressive and exploitative social system.

Limbale's main aim in writing Akkarmashi was to reveal his woes as the son of a whore. Upper caste people treated him as an untouchable, whereas his community ridiculed him by calling him Akkarmashi; hence he lived with a feeling of inferiority. To be a Dalit in a caste-based society is a curse, and to be an illegitimate within the Dalit caste is to be doubly cursed. Dalits are the "outcastes" of a society but a "half caste" among the outcaste is destined to live a subhuman existence. Akkarmashi acts as the mouthpiece of the community, revealing the inner self and mindscape of a Dalit, who has to suffer because of the hypocrisies and the malignant customs and traditions of the upper caste. In spite of the constitution offering many provisions that safeguard the interests of the Dalits, they still have to live a life of suffering, because of the well defined social hierarchy with caste at the center, that has thrived in India right from ancient times.

The next topic of discussion in Akkarmashi is on the identity of a Dalit. In general, a Dalit is identified and recognized by the roles given to him by the society, the roles here stands for the menial works and as a service provider to the upper castes devoid of any wages. A Dalit is like a slave to the upper caste Patils; they can command him/her according to their will, and Dalit has to carry out the orders without showing any resentment. Moreover, a critical study of Limbale's Akkarmashi defines a Dalit's identity about three aspects: First by birth, then by father's name, and finally by his/her caste. Throughout the narrative, Limbale tells about the crises of identity and always looks confused regarding his existence. Birth is the criteria defining the identity of a person in the very first stage, but Limbale is of the view that his birth is a curse for him since he was born out of an illegitimate relationship his mother had with a Patil. He writes:

Why did my mother say yes to the rape which brought me into this world? Why did she carry the product of this illegitimate sexual relationship for nine months and nine days and allow me to grow in the fetus? Why did she allow this bitter embryo to develop? How many eyes must have humiliated her because they considered her a whore? Did anyone distribute sweets to celebrate my birth? Did anyone admire me, affectionately? Did anyone celebrate my naming ceremony? Which family would claim me as its descendent? Whose son am I?

Born of a high-caste Patil and an untouchable Mahar, Limbale became an 'Akkarmashi,' as his parentage remained unacknowledged through wedlock. This curse of being 'fatherless' haunted Limbale throughout his life. It became the most heinous of obstacles and pushed him to a helpless situation, with everyone taunting him for being an 'Akkarmashi' within his own family and extended to the most crucial moments of his life like seeking admission in college and the prospects of marriage. Now and then, Limbale is cruelly made to take cognizance of his position within the positionless group of untouchables, by the hostile society. He laments: "A man is identified in the society by his religion, caste, or his father. Sadly, I don't have any of these markers of identity. I don't have any inherited identity at all".

The next major issue in Limbale's Akkarmashi is the economic deprivation faced by Dalits. The Dalits are landless and follow the traditional occupation, which impedes any kind of economic mobility in their lives. They work as laborers in the fields of rich landlords in exchange for a small amount of grain. In the wake of such economic exploitation, the Dalits have to face 
hunger and starvation. For them, food is God. A Dalit agrees to perform any kind of work to fill his/her belly. Nonetheless, there was no guarantee of employment regularly, and a Dalit had to remain unemployed for long durations. Limbal writes: "Every bus meant bread and butter for us. We waited at the bus stand for a bus just as a prostitute waits for her clients. The moment when I saw a bus coming, I became elated, hoping that this bus would provide us at least a few annas and Dada could buy me a cup of tea". Further, he goes on to write about the pathetic condition of the Dalits because of hunger: "Our village has provided us with bread so we owe much to them. They did provide bread but in exchange gratified their sexual desires with our women. I can't bear to think of my mother, Masami, caught in entanglement between bread and lust. Who will save my mother? She will die tainted, an object of someone's sexual pleasure".

Limbale's autobiography also takes up the question of the Hindu caste system and its religious dogmas, which boycott the Dalits from the mainstream society, tagging them as untouchables. Dalits have to lead a subhuman existence, being treated worse than animals and exploited in all possible ways by the institutions of caste and religion. Limbal protests: "How does a person become untouchable as soon as he is born? On what basis can he be a criminal by birth? From his feet, Brahma begot a vast low caste community. Since then, we have been living as untouchables". He further questions: "What sort of religious burden do we carry as a porter of his load? Why are we being tortured by thrusting this burden of religion on us? What on earth prevents us from discarding it? How come man has immersed himself under this diabolic tree of caste, religion, breeding, and family?"

However, Limbale does not admit defeat to his pathetic existence but acquires freedom and liberation from the predicament of caste through education. The knowledge he garnered from books enabled him to think differently. He realized that the suffering of Dalits had everything to do with some false, preconceived, and stereotypical notions that existed in the society and that the Dalits themselves were, in no way, responsible for it; it is this realization that liberates him. Limbal writes in his critical work, Towards an Aesthetic of Dalit Literature: "The conditions that I have written about, the socio-cultural milieu that I have written about, ceases to exist in my house now, because of my firm convictions and the position that I happen to hold today."

\section{ili. Conclusion}

From the perspective of a collective past, Limbale is every Dalit deemed untouchable. As a Dalit, he experiences split identification - as the product of an extramarital affair, as a Mahar and also as an educated
Dalit who has moved forward the social order than his community but at the same time forbidden from stepping up the established social order by the upper caste Hindus. As an autobiography, Akkarmashi displays all the features and qualities of a real-life narrative. But the significance of this work is beyond the narrow confines of an autobiography since it acts as a mouthpiece for the entire Dalit community. As such, we can place it on the highest pedestal of Indian literature. Limbale's travails portrayed so vividly is indicative of the magnitude of the challenges involved in the process of reclaiming dignity both for himself and his community.

\section{References Références Referencias}

1. Bharti, C. B. The Aesthetics of Dalit Literature. Chennai: Hyati, 1999.

2. Dasan, M. Mapping Marginality: Premises and Perspectives. Chennai: Emerald, 2011.

3. Ghose, Sagarika. The Dalit in India. New Delhi: Prestige Books, 2002.

4. Limbale, Sharankumar. The Outcaste: Akkarmashi. New Delhi: Oxford University Press, 2003. .Swain, S.P. Self-Identity in Indian Fiction. New Delhi: Prestige Books, 2001 